\title{
Cash Management and Bank's Financial Performance: Evidence from selected Deposit Money Banks in Nigeria
}

\author{
Ali I. Peter ${ }^{1}$, Peter N. O. Njoku², John N. N. Ugoani ${ }^{3}$, O. C. Nwaorgu ${ }^{4}$, Okanta S. Ukeje ${ }^{5}$ \\ ${ }^{1}$ Department of Accountancy, Imo State Polytechnic Umuagwo, P.M.B. 1472 Owerri, Imo State-Nigeria \\ 2,3 \&4College of Management \& Social Sciences, Rhema University, P.M.B. 7021 Aba, Abia State-Nigeria \\ ${ }^{5}$ Department of Banking and Finance, Abia State University, P.M.B. 2000 Uturu, Abia State-Nigeria
}

\section{Info Artikel}

Keywords:

Cash Management; Financial Performance; and Liquidity Management.

Kata Kunci:

Kinerja Keuangan; Manajemen kas; dan Manajemen Likuidtas

ISSN (print): 2598-7763 ISSN (online): 2598-7771

$\triangle$ Corresponding Author: Ali I. Peter

Tel. /Fax. -

E-mail:frpifyali@gmail.com

\section{Abtract}

This study empirically examined the effects and implications of cash management of DMBs in Nigeria. The variables studied were Cash to total asset, Operating cash to total asset, Investing cash to total asset, Financing cash to total asset, Bank size, Bank age, proxied for cash management and Return on Asset used to represent financial performance. Data used for this study were from secondary sources and were generated from the annual reports and accounts of the selected DMBs for the period 2014-2018. The results show that while operating cash to total asset of bank, investing cash to total asset and bank size have no significant effect on financial performance of DMBs, financing cash to total asset and bank age have a significant and positive effect on financial performance of deposit money bank $(D M B s)$. However, cash to total asset has a significant negative effect on financial performance of banks. The study concludes that cash positions, which can lead to liquidity risk has to be managed because it has tendency to compound other risks. It further highlighted that adequate attention should be paid on the use and reserves of cash among banks in Nigeria. This study recommends that banks should adopt optimum cash management model for efficiency and effectiveness. Stringent regulatory policies in this regard must be reviewed in such a way that they can be relaxed, to encourage effective liquidity management measures.

Citation: Peter, I. A.,Njoku, N.O., Ugoani, N.N.J., Nwaorgu, O.C. and Ukeje, S.O. (2020). Cash Management and Bank's Financial Performance: Evidence from selected Deposit Money Banks in Nigeria. AFRE Accounting and Financial Review. 3(2): 180-189

\begin{abstract}
Abstraks
Studi ini secara empiris menguji efek dan implikasi dari cash management DMBs di Nigeria. Variabel yang diteliti adalah Cash to total asset, Operasional cash to total asset, Investing cash to total asset, Financing cash to total asset, Bank size, Bank age, cash management dan Return on Asset digunakan untuk mewakili kinerja keuangan. Data yang digunakan berasal dari sumber sekunder dan berasal dari laporan tahunan dan rekening DMB terpilih untuk periode 2014-2018. Hasil penelitian menunjukkan bahwa sementara kas operasi terhadap total aset bank, kas investasi terhadap total aset dan ukuran bank tidak berpengaruh terhadap kinerja keuangan DMB. Kas pembiayaan terhadap total aset dan umur bank berpengaruh positif terhadap kinerja keuangan bank di Nigeria. Cash to total asset berpengaruh negatif terhadap kinerja keuangan bank di Nigeria. Hasil penelitian menyimpulkan bahwa posisi kas yang dapat menimbulkan risiko likuiditas harus dikelola karena memiliki kecenderungan untuk menambah risiko lainnya. Perhatian yang lebih pada penggunaan dan cadangan uang tunai pada bank-bank di Nigeria harus dilakukan. Studi ini merekomendasikan agar bank mengadopsi model pengelolaan kas yang optimal untuk efisiensi dan efektivitas. Kebijakan regulasi yang ketat dalam hal ini harus ditinjau kembali sedemikian rupa sehingga dapat dilonggarkan, untuk mendorong kebijakan langkahlangkah manajemen likuiditas yang efektif.
\end{abstract}

JEL Classification: G23, M41

DOI: https://doi.org/10.26905/afr.v3i2.5450 


\section{INTRODUCTION}

The import of cash management to financial performance of modern banking organisations is well established in literature (see for example, Bassey \& Moses, 2015; Wolfing \& Moormann, 2018; Shawar, 2019). Cash management implies a company's ability to allocate its funds efficiently in an effort to cover operating expenses, make investments, repay shareholders, and maintain adequate reserves. By generating enough cash, a business can meet its everyday business needs and avoid taking on debt. In doing so, the business has more control over its activities. Without generating adequate cash to meet its needs, the banking industry may likely find it difficult to conduct its routine activities such as good maintenance culture of the banking facilities, purchase of required machinery and tools (Non-current Assets) for banking activities, inability to grant loans to its customers, poor budgetary control, inability to maintain effective accounting system, may face liquidation, merge or even wind-up or liquidated, inability to invest, inability to pay its employees, as well as not meeting the required standards of operation as specified by the Central Bank of Nigeria (Akinyomi, 2014; Thangavel, 2018).

Although cash management is not a new issue among operators of banking firm (Chandeka \& Khedkar, 2014; Idowu, Essien, \& Adegboyega, 2017), it is particularly important for every organization as it pertains to the daily running of the organization, development, maintenance and growth. Cash is one of the most important assets in the Deposit Money Banks (DMBs) in Nigeria and should be managed efficiently to support growth and financial performance in Banks. A successful cash management plays a vital role in achieving this growth, strength and financial performance. Hence the adoption of sound cash management techniques to ascertain the extent of the liquidity of Deposit Money Banks (DMBs) is also important to measure the financial performance.

The main aim of keeping cash is to meet day-to-day financial needs of any institution, along with sufficient liquidity and adequate profitability portfolio. Consequently, banks and deposit taking institutions should strive to keep its cash and nearcash reserves within the requirements and limits in order to optimize, interpret and improve the overall liquidity needs of their clients and other stakeholders. This can be possibly achieved if a bank implements the accepted financial performance measures needed to regulate cash to total asset or operating cash to overall financial performance at a given period.

But the ideal situation should reflect cash management which is the most liquid asset representation of a larger percentage of a bank's current assets. This in a way shows a positive financial performance and standard required of deposit money banks (DMBs) in Nigeria. Bank should under all possible standards avoid unacceptable measures of keeping cash, such as over-holding of cash, cost of security and cost of insurance with National Deposit Insurance cooperation (NDIC) as these affect the profitability and financial performance of deposit money banks (DMBs) adversely.

However, a review of cash management and banks' financial performance literature to the best of the researcher's knowledge showed that research on the evaluation of cash management and banks' financial performance of deposit money banks (DMBs) in Nigeria had not been conducted by previous studies. Most of the studies focused on the determinant of commercial bank profitability. Emenike and Obasi (2016) studied the impact of marketing of bank services on DMBs profitability. Sameh and Jamel (2013) assess the effect of bank size on technical efficiency and its components: pure technical and scale efficiencies. They used a panel of 402 commercial banks from 15 developing countries over the period between 2000-2003 periods in their studies. Ongore and Kusa (2013) examined the factors affecting commercial banks financial performance in Kenya. Kwadwo (2018) investigated the determinants of bank profitability in Ghana and India. Amah, Michael, and Ihendinihu (2016) examined the relationship between cash flow and performance in the Banking sector of Nigeria. The study involved a survey of four (4) Banks quoted in the Nigeria Stock Exchange. Data were obtained from the annual report and accounts of selected Banks.

From the foregoing, the existing empirical literature from the studies reviewed showed that in Nigeria no current works have been done on cash management and banks' financial performance up to 2019. The work done in 2016 on the relationship of cash flow ratios and financial performance of banks in Nigeria used only four (4) banks and with 2013 annual reports and accounts. Also, the data selection method for the studies was not specified. The numbers of variables used 
in these works are either fewer or different from the ones in this study. The broad objective of this study is to fill this gap by evaluating the linkage between cash management and financial performance of Deposit Money Banks (DMBs) in Nigeria. Findings of this study and its recommendations will assist the monetary authorities to plan qualitatively on proactive measures to control the banks and other financial institutions' activities in Nigeria. In addition, the study will provide a reference to bank managers and deposit money banks to be able to make sound decisions with due regard to cash management and the risks associated with bank's financial performance. The findings will further contribute to the body of knowledge by providing to researchers and academics with some or new variables to close the gap(s) in literature

\section{HYPOTHESIS DEVELOPMENT}

Numerous empirical studies have investigated the impact of cash management on financial performance of business organisations across the globe. Duncan, Njeru, Member and Tirimba (2015) examined the effect of cash management on financial performance of deposit taking SACCOs in Mount Kenya Region. Their results indicated amongst others that cash management impacts financial performance. They concluded that there is need to introduce cash management controls in the SACCOs. Bassey and Moses (2015) examined the liquidity-profitability trade off of deposit money banks in Nigeria. The results revealed amongst others that there is a statistically significant relationship between bank liquidity measures-current ratio, liquid ratio, cash ratio, loans to deposit ratio, loans to asset ratio- and return on equity. Another study by Smirat (2016) examined empirically the cash management practices and its effect on the financial performance of SMEs in Jordan, and reported and that cash management practices have influence on the financial performance of SMEs. Okaro and Nwakoby (2016) assessed the effects of liquidity management on performance of deposit money banks (DMBs) in Nigeria. Four specific objectives were made from the broad objective which includes: to determine the relationship between liquidity ratio and profitability, to ascertain the relationship between cash to deposit ratio and profitability among others. To address the objectives, research questions and stated hypotheses, relevant data were gathered from CBN and NDIC annual publications for 16years covering 2000-2015. The result of the OLS showed that there is a negative and significant relationship between liquidity ratio and DMBs' profitability and there is a positive and significant relationship between cash to deposit ratio and profitability of the DMBs. Emenike and Obasi (2016) reported amongst others, evidence of positive long-run relationship between marketing of bank services on DMBs financial performance in Nigeria. A later study by Alice and Mulyungi (2018) analyzed the effect of cash management on the financial performance of cooperatives banks in Rwanda. The results further revealed a strong relationship between cash management and financial performance. The study concluded that cash management is a key tool in the financial management of the banks since cash forms the biggest asset of the bank. Using insurance data from Pakistan, Shawar (2019) documented amongst others that size of the company has a negative impact on sales and investment profit.

A plethora of empirical studies have equally evaluated the determinants of financial performance. Gemechu (2016) for example examined the effect of bank-specific, industry-specific and macroeconomic determinants on banks' profitability in Ethiopia. The study applied balanced panel data of eight Ethiopian commercial banks that covers the period of 2002 - 2012. The paper uses ordinary least square (OLS) technique to see the impact of determinants on profitability of Ethiopian commercial banks. The findings of the study show amongst other that all bank specific determinants except credit risk and expense management have statistically significant and positive relationship with banks' profitability. On the contrary, Kalu, Shieler and Amu (2018) documented evidence to show that credit risk identification and credit risk appraisal has a strong positive relationship on financial performance of MDIs, while credit risk monitoring and credit risk mitigation have moderate significant positive relationship on financial performance of microfinance institutions in Uganda. Similarly, Abubakar et al (2019) showed that capital adequacy ratio, return on asset and loansto-deposit ratio have positive and significant effect on the financial performance; while nonperforming loans ratio, cost-to-income ratio and liquidity ratio have no significant effect of the financial performance measured by the return on equity.

$\mathrm{H}_{1}$ : There is no significant relationship between cash to total asset and financial performance of deposit money banks in Nigeria.

$\mathrm{H}_{2}$ : Operating cash to total asset does not significantly affect finance performance of deposit money banks in Nigeria. 
$\mathrm{H}_{3}$ : There is no significant relationship between investing cash to total assets and financial performance of deposit money banks in Nigeria.

$\mathrm{H}_{4}$ : There is no significant relationship between financing cash to total assets and financial performance of deposit money banks in Nigeria.

On the linkage between bank size and age Kutsienyo (2011) for example examined the determinants of bank profitability in Ghana using panel data of 26 commercial banks in Ghana for the 20002009 period. Two key measures of profitability were analyzed in this study comprised of Return on Average Asset (ROA) and Return on Average Equity (ROE) and capital adequacy, operating expense, liquidity, asset quality, and bank size were incorporated into the regression models as bankspecific factors, in addition to inflation, Gross Domestic Products (GDP), money supply and banking industry concentration, which were added as macroeconomic factors and financial structure factors. The results showed amongst others that capital adequacy, liquidity and bank size are positively significant to bank profitability while asset quality and operating expense are negatively significant to bank profitability. Babalola (2013) investigated the effect of firm size on the profitability of manufacturing companies listed in the Nigerian Stock Exchange. The results showed that firm size, both in terms of total assets and in terms of total sales, has a positive impact on the profitability of manufacturing companies in Nigeria. A related study by Sameh and Jamel (2013) assessed the effect of bank size on technical efficiency and its two components: pure technical and scale efficiencies using a panel of 402 commercial banks from 15 developing countries over the period between 2000-2003 periods. The results indicated that the bank size impacts technical efficiency. A later study by Mohammad (2015) investigated the effect of bank size on its profitability for Jordanian listed commercial banks within different size bank categories. The results of the study revealed a significance difference in the profitability of these different sized banks. Amahalu and Ezechukwu (2017), studied the extent at which firm characteristics affects financial performance of quoted deposit money banks in Nigeria from 2010-2015. The results showed that size have a positive and statistically significant effect on financial performance. A more recent study by Kwadwo (2018) showed empirically that cost to income ratio and bank size had an insignificant impact on profitability of Indian banks but impacted significantly on Ghanaian bank's profitability.

$\mathrm{H}_{5}$ : Bank Age has no significant effect on financial performance of deposit money banks (DMBs) in Nigeria.

$\mathrm{H}_{6}$ : Bank Size has no significant effect on financial performance of deposit money banks (DMBs) in Nigeria.

\section{DATA AND METHOD}

The scope of this study is Nigeria. The secondary source of data collection method was adopted in this study. Specifically, this study made use of annual financial reports and accounts of selected Deposit Money Banks (DMBs) whose shares were listed with the Nigerian Stock Exchange (NSE) as at 31st December, 2018. The period under consideration spans between 2014 and 2018. Data generated from the annual reports and account would be used for this study analysis. Banks selected for this study are; First Bank of Nigerian Plc., United Bank of Africa (UBA), Zenith Bank Plc., Access Bank Plc. and Guarantee Trust Bank plc. (GTB). The reasons for the selection are because they are among the current top seven (7) best banks in Nigeria based on recent rankings (lists.ng, 2019) and with high capital base and revenues. The choice of 2014 is premised on the fact that the financial reports prepared and presented in these periods were International Financial Reporting Standards (IFRS) compliant, while the choice of 2018 financial year was based on its currency and availability of data as at the time of this study. The sampled banks for this study were presented in table 1 .

The most common method of analyzing a company's financial performance has been the measuring of its corporate financial disclosure in the annual reports using the content analysis technique (Milne \& Adler, 1999). This is because it allows corporate financial performance to be systematically classified and compared, which is useful for determining trends, making replicable and valid inferences from data according to their context (Uwuigbe, 2011; Sanyaolu, Adesanmi, Imeokparia, Sanyaolu, \& Alimi, 2017).

In this context, we evaluated financial performance with respect to banks cash management in Nigeria. Data generated from the annual reports and accounts were analyzed using descriptive statistic and econometric statistical software (E-view 10+). The statistical tool employed was the Ordinary Least Square (OLS) regression. The multiple linear regression models was specified 
and estimated in this study. The multiple linear regression equation was used to determine the relationship between cash management and banks financial performance.

Table 1. Best Five (5) of the Seven (7) Top Rated Banks in Nigeria

\begin{tabular}{|c|c|c|c|c|}
\hline Name of banks & $\begin{array}{c}\text { Total deposit } \\
N\end{array}$ & $\begin{array}{c}\text { Total assets } \\
\ldots\end{array}$ & $\begin{array}{c}\text { Gross earnings } \\
\ldots\end{array}$ & Shareholders fund \\
\hline First Bank of Nigerian Plc. & 25.7 Tri. & 25Tri. & 44 Billion & 71 Billion \\
\hline Zenith Bank Plc. & 25 Trillion & 14 Tri. & 4 Billion & 3 Billion \\
\hline Guarantee Trust Bank Plc. (GTB). & 44 Trillion & 1 Tri. & 242 Billion & 35 Billion \\
\hline Access Bank Plc. & 33 Trillion & 8 Tri. & 207 Billion & 5 Billion \\
\hline United Bank of Africa (UBA). & 8 Trillion & 22 Tri. & 264 Billion & 54 Billion \\
\hline
\end{tabular}

Source: Lists.ng, 2019

Given the dynamic nature of the panel data that was used in this study and in line with Minnick and Noga (2010) and Salawu and Adedeji (2017), this study imposed a linear relationship between banks financial performance and the explanatory variables which are banks operating activities that potentially explain variation in cash management. This study adapts the model of Alice (2015). The variables specified in the modified model are cash to total asset, operating cash to total asset, investing cash to total asset, bank size and bank age proxied for cash management (independent variables) while returns on asset was used as proxy for financial performance (dependent variable). Using a linear regression of banks financial performance on the exogenous variables, the model is expressed functionally as:

Financial performance $=\mathrm{F}$ (Cash to total asset, Operating cash to total asset, Investing cash to total asset, Financing cash to total asset, Bank age, Bank size).

However, the econometric model is expressed thus:

\section{$\mathrm{ROA}=$ bo $+\beta_{1} \mathrm{CSHA}+\beta_{2} \mathrm{OPTA}+\beta_{3} \mathrm{INTA}+\beta_{4} \mathrm{FITA}+$ $\beta_{5} \mathrm{BAGE}+\beta_{6} \mathrm{BSIZE}+\mathrm{v} \varepsilon$}

Where: $\mathrm{ROA}=$ Return on Asset, $\mathrm{CSHA}=$ Cash to total assets, OPTA=Operating cash to total assets, INTA $=$ Investing cash to total assets, FITA $=$ Financing cash to total assets, $\mathrm{BAGE}=$ Bank age, BSIZE $=$ Bank size, $\mathrm{a}=$ Regression constant, $\varepsilon=$ Error term normally distributed about the means of zero. $\beta_{1}, \beta_{2}, \beta_{3}, \ldots \ldots \beta_{n}$, are the coefficients of the variation that determine the change of each variable to financial performance in the regression model.

The variables used in this model are shown in Table 2 and Variables used in this study were measured as shown in Table 3.

Table 2. The dependent and Independent Variables

\begin{tabular}{lll}
\hline Variables & \multicolumn{1}{c}{ Specification } & Class of variable \\
\hline ROA & Return of Asset & Dependent \\
CSHA & Cash to Total Assets & Independent \\
OPTA & Operating Cash to Total Assets & Independent \\
INTA & Investing Cash to Total Assets & Independent \\
FITA & Financing Cash to Total Assets & Independent \\
BAGE & Bank Age & Control \\
BSIZE & Bank Size & Control \\
\hline
\end{tabular}

Table 3. Measurement of Variables

\begin{tabular}{lll}
\hline S/N & Variables & Measurement \\
\hline 1. & Financial Performance & Return on Asset \\
2. & Return on Asset2 & Profit after Tax divided by Total Asset \\
3. & Cash to total assets & The proportion of cash to total assets for the year \\
4. & Operating cash to total assets & The proportion of operating cash to total assets for the year \\
5. & Investing cash to total assets & The proportion of investing cash to total assets for the year \\
6 & Financing cash to total assets & The proportion of financing cash to total assets for the year \\
7. & Bank Size & The natural log of total assets \\
8. & Bank age & The number of years since incorporation of the bank to the observation \\
& & date
\end{tabular}




\section{RESULTS}

\section{Descriptive Statistics}

The statistical tool used in this study is the descriptive statistics which help to explain the behaviour of the data set in their level set. The statistics presented identify the behavioural patterns of the individual time series data used in the study. Two summary statistics are presented in this section. The first one considers individual banks in the sample, while the second one considers all the banks together. The descriptive statistics for each of the variables for the respective banks are presented in table 4 below. From the Table, it is seen that GTBank had the highest average performance indicator, suggesting that the bank has the most efficient operational performance among the selected banks. On the other hand, First Bank had the lowest ROA value of 0.93 among the banks. The ratio of operating cash to total asset is highest for GTB and Zenith banks, while UBA has the lowest ratio among the banks.

Table 4. Descriptive Statistics for Individual Banks

\begin{tabular}{llllllll}
\hline Bank & ROA & OPTA & INVA & FITA & CSHA & BSIZE & BAGE \\
\hline First Bank Plc & 0.93 & 0.09 & 0.22 & 0.03 & 0.68 & 3.25 & 122 \\
GTB Plc & 4.52 & 0.13 & 0.18 & 0.07 & 0.68 & 0.90 & 26 \\
Zenith Bank Plc & 2.49 & 0.13 & 0.03 & 0.06 & 0.77 & 0.86 & 26 \\
UBA Plc & 1.99 & 0.05 & 0.26 & 0.05 & 1.45 & 0.64 & 55 \\
Access Bank Plc & 2.10 & 0.11 & 0.22 & 0.04 & 0.68 & 1.12 & 27 \\
\hline
\end{tabular}

For investing cash to total asset (INVA), UBA has the highest value and Zenith bank has the least value. This implies that though UBA has less total cash ratio, the bank applies a very large proportion of the available cash for investment purposes. With a ratio of 0.7 , GTB has the highest Financing Cash to Total Assets among the banks in the sample. In terms of total cash to total assets, UBA has the highest value of 1.45 among the banks in the sample, while three of the banks; First bank, GTB and Access bank all have the same cash ratio of 0.68 percent. It appears that these banks are keeping in line with the $\mathrm{CBN}$ provisions for cash reserves ratios among banks in

Table 5. Descriptive Statistics (combined)
Nigeria. If this is the case, then, UBA has exceeded the ratio quite remarkably.

In Table 5, the descriptive statistics for all the banks are presented. The average ROA for all the banks is 2.41, which is relatively high. The standard deviation value of 1.27 for the ROA indicates that the ROA was relatively similar among the banks in the sample. Average bank age is also 51 years, although a bank like First bank dominates others in terms of age. The average cash ratio for all the banks is 3.46 percent (relative to total assets), while average operating cash ratio is 0.1 percent, which is very low. On average, investing cash ratio (INVA) is the largest in terms of application of cash management among the banks.

\begin{tabular}{lcccllllll}
\hline Variable & Mean & Median & Max & Min & \multicolumn{1}{l}{ Std. Dev. Skewness } & Kurtosis & J-B & Prob \\
\hline CSHA & 3.46 & 0.70 & 70.00 & 0.57 & 13.86 & 4.69 & 23.04 & 510.19 & 0.00 \\
OPTA & 0.10 & 0.06 & 0.40 & 0.01 & 0.09 & 1.67 & 5.86 & 20.16 & 0.00 \\
INVA & 0.18 & 0.20 & 0.57 & 0.00 & 0.14 & 0.79 & 3.73 & 3.15 & 0.21 \\
FITA & 0.05 & 0.05 & 0.10 & 0.01 & 0.03 & 0.45 & 2.24 & 1.47 & 0.48 \\
BSIZE & 1.36 & 0.74 & 5.22 & 0.07 & 1.40 & 1.23 & 3.50 & 6.60 & 0.04 \\
BAGE & 51.20 & 28.00 & 124.00 & 24.00 & 37.89 & 1.21 & 2.77 & 6.12 & 0.05 \\
ROA & 2.41 & 2.11 & 5.14 & 0.36 & 1.27 & 0.65 & 3.02 & 1.79 & 0.41 \\
\hline
\end{tabular}

Most of the cash management indicators also have J-B values that are not normally distributed (since the probabilities of the J-B values are less than 0.05). Non-normal distributions imply that the series may vary on the basis of different cross sections. This is also the case for all the other variables in the sample for this study (apart from ROA, FITA and OPTA). This outcome clearly shows that the use of panel data analysis procedure for the estimation of the relationships in this study stems from heterogeneity in all the data series.

The correlation matrix among the datasets is also presented in Table 6. Only the correlations among ROA, FITA, bank size and bank age are significant in the Table. There is a negative correlation between bank age and FITA, implying that older banks tend to devote less cash for financing purposes. Surprisingly, there is no correlation among the cash management variables for the 
banks. This implies that the use and conservation of cash are not correlated among the banks. For instance, increasing cash availability for investing purposes does not lead to increases in cash provisions for financing purposes.

The correlation tests show the initial patterns of relationships among the variables. How- ever, it does not show the individual distribution of the data in terms of probability density over the period of the sampling. Hence, this section proceeds to test for the distribution patterns of the density functions for the residual in the data for the study since the aim of the study is to examine and estimate a panel data model.

Table 6. Correlation Matrix

\begin{tabular}{lllllll}
\hline & CSHA & OPTA & INVA & FITA & BSIZE & BAGE \\
\hline OPTA & -0.143 & & & & & \\
& $(0.495)$ & & & & \\
INVA & -0.170 & -0.099 & & & \\
& $(0.417)$ & $(0.638)$ & & & \\
FITA & 0.009 & 0.299 & -0.120 & & & \\
& $(0.966)$ & $(0.147)$ & $(0.567)$ & & & \\
BSIZE & -0.094 & -0.134 & 0.164 & -0.078 & & \\
& $(0.654)$ & $(0.523)$ & $(0.433)$ & $(0.710)$ & & \\
BAGE & 0.009 & -0.154 & 0.260 & -0.363 & 0.635 & \\
& $(0.966)$ & $(0.463)$ & $(0.210)$ & $(0.075)$ & $(0.001)$ & \\
ROA & -0.111 & 0.180 & -0.096 & 0.407 & -0.405 & -0.668 \\
& $(0.598)$ & $(0.389)$ & $(0.649)$ & $(0.043)$ & $(0.044)$ & $(0.000)$ \\
\hline
\end{tabular}

\section{Regression Analysis}

This section focuses on the estimation and analysis of the regression results based on the specified model in section three. In the regression result, the panel data analytical framework was adopted, although the random effects estimated could not be reported. This is because the number of banks in the sample (5) is less than the number of coefficients to be estimates (seven). Enders (2015) has noted that when the cross sections in a panel are lesser than the number of estimated coefficients, the estimation of random effects from a panel dataset becomes impossible. Hence, only the OLS and the fixed effects estimates are reported.

Table 7 shows the estimated results. The results posses' impressive goodness of fit coefficients, especially considering the fact that panel data is used in the study, which initially reduces the size of the diagnostic indicators (Iyoha, 2004). Given that only the fixed effects estimates correctly reports the relationships, we focus on the results. From the results, the R-squared value for the fixed effects estimates is 0.504 , which shows that about 50 percent of the systematic variations in ROA among the banks were captured by the estimated model. This is a rather impressive value and suggests that the estimated model has a high explanatory capacity. The F-value is low, though it passes the significance test at the 5 percent level. Thus, the model has a strong overall significance.

Table 7. OLS and Fixed Effects Estimates

\begin{tabular}{lllllll}
\hline & \multicolumn{3}{l}{ OLS estimates } & \multicolumn{4}{l}{ Fixed effects estimates } \\
Variable & Coefficient & t-Statistic & Prob. & Coefficient & t-Statistic & Prob. \\
\hline OPTA & 2.890 & 3.725 & 0.002 & 2.884 & 2.282 & 0.039 \\
INVA & 0.290 & 0.161 & 0.874 & 0.547 & 0.169 & 0.869 \\
FITA & 0.662 & 0.577 & 0.571 & 0.694 & 0.334 & 0.743 \\
CSHA & 9.185 & 1.998 & 0.052 & 8.885 & 2.042 & 0.047 \\
BSIZE & -0.009 & -2.190 & 0.049 & -0.012 & -2.337 & 0.004 \\
BAGE & -0.029 & -0.133 & 0.896 & -0.060 & -0.207 & 0.839 \\
R-squared & 0.020 & 2.975 & 0.008 & 0.019 & 2.317 & 0.036 \\
F-stat & 0.494 & & & 0.504 & & \\
\hline
\end{tabular}

In terms of the individual performance of each of the coefficients of the model, the result shows that the coefficients of FITA and CSHA are the only significant coefficients among the cash management variables. The probability value for FITA is 0.047 , while that of CSHA is 0.004 , implying that they both pass the significance test at the 5 percent level (i.e., less than 0.05 ) thus, the result 
shows that cash allocation for financing purposes has a significant positive impact on bank financial performance. The larger the cash available for financing, the more efficient the banks will be in boosting financial performance. The result also shows that overall cash management in the banks tends to stiffen financial performance. This is seen from the negative and significant coefficient of CSHA in the result. This implies that as the banks vote more funds for cash activities or reserves, the banks tend to lose efficiency in financial management. The other cash management variables fail the significance test at the 5 percent level. This implies that cash for investment and other operational activities do not have significant impacts on bank financial performance, on the basis of the sample of the study. The coefficient of bank age is significant and positive, suggesting that older banks are more efficient in financial activities compared with newer banks in Nigeria.

\section{DISCUSSION}

It is important to examine the role of cash holding and the management of cash in the performance evaluations of banks. The results obtained from the empirical analysis of the study are quite interesting and apt in terms of policy evaluations. First, the study has found that the larger the cash available for financing, the more efficient the banks will be in boosting financial performance. This implies that voting more cash in the banks for use can hinder overall performance in terms of efficiency. This result is partly in consonance with the study by Edem (2017) who found that there is a significant relationship between liquidity management and the performance of Deposit Money Banks in Nigeria. However, only the banks with optimum liquidity were able to maximize returns on assets. Thus, it is seen that excess liquidity pose problem to bank management operations (Ajibike \& Aremu, 2015).

Since the larger the cash available for financing purposes, the more efficient the banks will be in boosting financial performance, this implies that the banks need to be careful in terms of their cash applications and management. Soyemi et al. (2013) found similar results and warned that a major cause of bank failures is low levels of liquidity and cash applications.

To curb this scenario, the Basel Committee on Banking Supervision initially published principles for sound liquidity risk management and supervision in 2008, which provided detailed guidance on the risk management and supervision of funding liquidity risk. The Committee has further strengthened its liquidity framework by developing minimum global liquidity standard called the Liquidity Coverage Ratio (LCR). This standard, an essential component of the Basel III reform is aimed at enhancing overall liquidity risk management by achieving the objective of increasing short-term resilience of a bank's liquidity risk profile (BCBS, 2015).

\section{CONCLUSIONS AND SUGGESTION}

The importance of cash management goes beyond the individual bank as liquidity shortfall at any individual bank can have systemic repercussions. A high liquidity ratio indicates a less risky and less profitable bank. Cash positions, which can lead to liquidity risk has to be managed because it has tendency to compound other risks. Hence, this study examined the issues of cash management among Nigerian banks, and the implications and effects of cash management on the banks. Using data covering the period 2012 to 2018, a sample of five banks was collected for the empirical analysis. Both statistical and econometric tools were employed in the empirical analysis of the study. Based on the empirical investigation, the following findings were made: 1) That cash to total asset has a significant negative impact on financial performance of deposit money banks (DMBs) in Nigeria. 2) That operating cash to total asset of banks does not have any significant effect on financial performance of deposit money banks (DMBs) in Nigeria. 3) That investing cash to total asset has no significant effect on financial performance of deposit money bank (DMBs) in Nigeria. 4) That financing cash to total asset has a significant and positive impact on financial performance of deposit money bank (DMBs) in Nigeria. 5) That bank age also exerts positive and significant effect on financial performance of deposit money bank (DMBs) in Nigeria. 6) That bank size has no significant impact on financial performance of deposit money bank (DMBs) in Nigeria.

Overall, our study shows that excessive cash or liquidity reduces profitability as unguided pursuit of maximum profitability could lead to the insolvency of a bank. The study further highlights that adequate attention be paid to the use and reserves of cash among banks in Nigeria. Apparently, a good banker should try to reconcile the twin conflicting objectives by actually work- 
ing out a good portfolio mix. This can be done by analyzing the situation, studying the objectives and therefore choosing a diversified and balanced asset portfolio.

Consequent on the critical evaluation of the findings made in this study, a number of recommendations are presented both with respect to policy and operational effects. First, the banks need to pay closer evaluation of their cash management by using appropriate measures to guide against illiquidity or excess liquidity. It is recommended that banks should adopt optimum cash management model for efficiency and effectiveness.

Since the survival of deposit money banks depend on cash or liquidity management and profitability, they should not solely concentrate on the profit maximization concept but also adopt measures that will ensure effective liquidity management. The measures will help to minimize or avoid cases of excessive and deficient liquidity as their effects are negative.

Instead of keeping excessive cash as a provision for unexpected withdrawal demands of the customers, the deposit money banks should find it reasonable to adopt other measures of meeting such requirements, which can include borrowing and discounting bill.

Stringent regulatory policies in this regard should be revisited such that they are either relaxed or expunged to pave way for policies that stimulate effective liquidity management measures. The recent implementation of the Treasury Single Account by the Nigerian government is a step in the right direction. This move will enhance the seriousness of banks management in managing their liquidity affairs and as well do away with over- dependence on government funds.

\section{REFERENCES}

Abubakar, A., Sulaiman A. S., Usman, B., \& Mohammed, M. U. (2019). Credit risk management and financial performance of quoted deposit money banks in Nigeria. Journal of Finance, Accounting and Management, 10(1), 57-74.

Ajibike, J.O. and Aremu, O. S. (2015). The impact of liquidity on Nigerian bank performance: A dynamic panel approach. Journal of African Macroeconomic Review, 5(2),23-41.

Akinyomi, O.C. (2014). Effect of cash management on profitability of Nigeria manufacturing firms. International Journal of Mar- keting, 4 (1), 129-140.

Alice, G., (2015). The effect of bank size on profitability of commercial banks in Kenya. Unpublished research project submitted in partial fulfillment $f$ the requirements for the award of the degree of Master of Science Finance, school of business, University of Nairobi.

Alice, M. \& Mulyungi, P. (2018). Effect of cash management on the financial performance of cooperative banks in Rwanda: A case of Zigma CSS. Invention Journal of Research Technology in Engineering $\mathcal{E}$ Management (IJRTEM) www.ijrtem.com 2 (5) 88-98.

Amahalu, N. \& Ezechukwu, B. (2017). Effect of firm characteristics on financial performance of quoted deposit money banks in Nigeria.

https://www.researchgate.net/publication /318681587_Effect_Of_Firm_Characteristics _On_Financial_Performance_Of_Quoted_D eposit-Money_Banks_in_Nigeria/Citation /Download.

Amah, K. O., Michael, C. E. \& Ihendinihu, J.U. (2016). Relationship of cash flow ratio and financial performance of listed banks in emerging economics- Nigeria example.

European Journal of Accounting, Auditing and Finance Research, 4 (4), 89-97.

Babalola, Y. A., (2013). The effect of firm size on firms profitability in Nigeria. Journal of Economics and Sustainable Development.

Bassey, G. E. \& Moses, C. E. (2015). Bank profitability and liquidity management: A case study of selected Nigerian deposits money banks. International Journal of Economics, Commerce and Management United Kingdom, III (4).

Central bank of Nigeria (CBN) annual statistical bulletin

https://www.cbn.gov.ng/Out/

2019/FPRD/Copy\%20of\%20DMBs\%20DAT ABASE \%20AS\%20AT\%20JULY\% 2019,\%202 019.pdf. Retrieved 19/07/2019.

Chandekar, M. G., \& Khedkar, A. M. (2014). Role of cash management system in banking sector. Research Journal of Management Sciences 3(12), 15-17.

Duncan, N. M., Njeru, A., Member, F., \& Tirimba, O. I. (2015). Effect of cash management on financial performance of deposit taking SACCOs in Mount Kenya Region. International Journal of Scientific and Research Publications, 5(2), www.ijsrp.org. 
Edem, D.B. (2017). Liquidity management and performance of deposit money banks in Nigeria (1986-2011): An investigation. International Journal of Economics, Finance and Management Sciences. 5(3), 146-161. doi: 10.11648/j.ijefm.20170503.13

Emenike, K. O. \& Obasi, R. (2016). Long-run relationship between marketing of bank services and the performance of deposit money banks in Nigeria. International Journal of Economics, Business and Management Studies, $3(1), 12-20$.

Enders, W. (2004). Applied Econometric Time Series ( $2^{\text {nd }}$ Ed.). Singapore: John Wiley \& Sons (ASIA) Pte Ltd.

Gemechu, A. S. (2016). Determinants of banks' profitability: Evidence from banking industry in Ethiopia. International Journal of Economics, Commerce and Management, United Kingdom iv (2), 442.

Idowu, A. A, Essien, J. M. \& Adegboyega, R. (2017). Liquidity management and banks performance in Nigeria. Issues in Business Management and Economics, 5 (6), 88-98.

Kalu, E.O., Shieler, B \& Amu, C.U. (2018). Credit risk management and financial perfomance of microfinance institutions in Kampala, Uganda. Independent Journal of Management $\mathcal{E}$ Production, 9(1), 153-169.

Kutsienyo, L. (2011). The determinant of profitability of banks in Ghana. A Thesis submitted to the Institute of Distance Learning, Kwame Nkrumah University of Science and Technology in partial fulfillment of the requirements for the degree of Commonwealth Executive Masters of Business Administration (CEMBA).

Kwadwo, B. (2018). Determinants of bank profitability: A comparative study of Indian and Ghanaian banks. Journal of Emerging Technologies and Innovative Research (JETIR); 5(5) 643-654. www.jetir.org.

Masonson, L. (2010). How to manage the business cash flow effectively. Retrieved June 12, 2019,

Milne, M. J. \& Adler, R. W. (1999): Exploring the reliability of financial disclosures content analysis. Accounting, Auditing and Accountability Journal, 12(2), 237-256.

Minnick, K., \& Noga, T. (2010). Do corporate governance characteristics influence taxmanagement? Journal of Corporate Finance, 16, 703-718

Mohammad, S. A. (2015). The impact of bank size on profitability "An empirical study on listed Jordanian commercial banks." European Scientific Journal December 11(34).

Ongore, V. O. \& Kusa, G. B. (2013). Determinants of financial performance of commercialbanks in Kenya. Int. J. Econ. Finance. Issues3.

Salawu, R. O., \& Adedeji, Z. A. (2017). Corporate governance and tax planning among non- financial quoted companies in Nigeria. An international multi-Disciplinary Journal, Dahir Dar, Ethiopia, 11 (3), 42-59.

Sameh, C.K., \& Jamel, E.C. (2013). Bank size and efficiency in developing countries: intermediation approach versus financial valueadded approach and impact of nontraditional activities. Asian Economic and Financial Review, 3(5):593-613.

Sanyaolu, O. A., Adesanmi, A.D., Imeokparia, L., Sanyaolu, A. O., and Alimi, A. (2017). Corporate governance and financial performance of quoted deposit money banks in Nigeria. International Journal of Social Science and Economic Research, IJSSER; 02(08).

Shawar, K. (2019). Factors affecting financial performance of insurance industry in Pakistan. Research Journal of Finance and Accounting, 10 (5).

Smirat, B. Y. AL (2016). Cash management practices and financial performance of small and medium enterprises (SMEs) in Jordan. Research Journal of Finance and Accounting, 7(2).

Uwuigbe, U. (2011). Corporate environmental reporting practices: A comparative study of Nigerian and South African firms. Ph.D. thesis submitted to the school of postgraduate studies Covenant University, Ota, Nigeria.

Wolfing, D. \& Moormann, J. (2018). Cash management in transition: From cash management to cash process management. Frankfurt School of Finance \& Management. 